\title{
“SonoDerm”, curs Euroson de succes orientat către o nouă aplicație a ultrasonografiei: patologia cutanată
}

În perioada 23 - 24 februarie 2019 a avut loc la Cluj-Napoca cursul european de ultrasonografie cutanată, intitulat „SonoDerm”. Organizat sub coordonarea EFSUMB, SRUMB și a UMF „Iuliu Hațieganu” din Cluj- Napoca, a avut ca și co-directori pe Prof. Maria Crișan (Cluj Napoca, România), Prof. Fernando Alfageme (Madrid, Spania) și Prof. Radu Badea (Cluj Napoca).

În anul 2017 la Orlando în cadrul AIUM (Institutul american de Ultrasonografie în Medicină), Ximena Wortsman a inițiat un grup de lucru multidisciplinar, internațional DERMUS, care și-a propus promovarea ultrasonografiei cutanate prin cursuri performante, acreditate, sesiuni practice interactive. În anul 2018 în Spania, la Madrid s-a organizat cursul de sonografie cutanată nivel I EUROSON sub egida EFSUMB şi un simpozion dedicat tot sonografiei cutanate cu ocazia Congresului EADO (Asociația Europeană de Dermato-oncologie) la Barcelona, în data de 8 noiembrie.

Motivația principală a cursului organizat la Cluj a fost necesitatea formulată de un număr de specialități clinice (dermatologie, oncologie, chirurgie plastică) de a beneficia, prin performanțele tehnologice ale ultrasonografiei cu rezoluție înaltă (cu frecvențe între $15-75 \mathrm{MHz}$ ), de vizualizare la nivel de detaliu a tegumentului normal și patologic. Au fost prezentate aspecte de anatomie și ecoanatomie normală și patologică a tegumentului, stadiul actual al metodei ultrasonografice, tehnici și moduri de explorare, particularități imagistice ale tumorilor cutanate, valoarea metodei în evaluarea limfonodulilor tumorali, utilitatea ultrasonografiei în cosmetologie și iatrogenii.

La curs au participat 108 de cursanți înregistrați (dintre aceștia 11 au fost din Rusia, Polonia, Israel, Brazilia, Lituania și Austria) și 12 lectori (din Rusia, Chile, Italia, Spania, Israel, Germania, România). Formatul cursului a fost combinat: prelegeri teoretice, demonstrații practice pe pacienți voluntari, examinări efectuate de către cursanți). De subliniat interesul mare al medicilor tineri, cca. $30 \%$ dintre cursanți fiind medici rezidenți de dermatologie. S-au organizat
7 ateliere practice cu echipamente Hitachi, Japonia și Taberna Pro Medicum (TPM), Germania.

Cel puțin două aspecte ar trebui scoase în evidență: a. au participat majoritatea profesorilor de dermatologie din România, care au hotărât să identifice soluții pentru implementarea ultrasonografiei cutanate fie în sistem de competență fie prin introducerea metodei în curicula medicilor rezidenți; b. între lectori s-a aflat prof. Ximena Wortsman (Chile), personalitate științifică și profesională excepțională, care a demonstrat valoarea indubitabilă a metodei pentru medicul practician în oncologie și cosmetologie.

Evaluările cursului au fost foarte bune. Putem considera acest curs ca fiind un succes și un eveniment de bun augur pentru anul 2019 al SRUMB.

Prof. Radu Badea 